\title{
Money-Transaction-Income Process: Quantification of Quantity Theory of Money
}

\author{
Bijan Bidabad $^{1}$
}

\begin{abstract}
In this paper, we try to establish the relationship between money and income via transaction. In this regard, we use different processes of value-added production in the economy to find this lost chain in literature. According to our findings, we reformulate and generalize the quantity theory of money. Our empirical investigations confirm our model formulations.
\end{abstract}

Keywords: Money, Quantity theory, Fisher, Transaction, Income

\section{Introduction}

Fisher's quantity theory of money establishes an exact relationship between money and transactions. But, other economists tried to link money to income via quantity theory of money by assuming that real income is a suitable scale variable for the total volume of transactions. This assumption simply relates money to income without reliable economic evidence. Consider the following two equations. Equation (1) is the original Fisher's quantity theory, and equation (2) is the other's interpretation of quantity theory.
$\mathrm{MV}=\mathrm{Pt}=\mathrm{T}$
$\mathrm{MV}=\mathrm{Py}=\mathrm{Y}$
Where,
M: Stock of money.
V: Velocity or circulation of money.
P: Price level.
y: Real Income.
Y: Nominal income.
$\mathrm{t}$ : Volume of transaction.
T: Value of transaction.

In the equation (1), Fisher discusses around the quantity and value of goods and services sold, but by equation (2), other economists interpret that income is a suitable scale variable for transaction, and they link MV to income (produced value added) in the economy by simply replacing " $y$ " by " $t$ ". In this section, now, we are going to determine the exact relationship between these two fundamental variables. On the other hand, it is tried to bridge between Fisher's original quantity theory $(\mathrm{MV}=\mathrm{Pt})$ and revisionists' interpretation of quantity theory $(\mathrm{MV}=\mathrm{Py})$ in a logical frame.

\section{Value of transactions in the production process}

To find out the relationship of value added (income) to the amount of nominal payment required to perform corresponding transactions; we try to follow the procedure that value added is produced in the economy. Before going through discussions, it should be cited that in all of the procedures of national income accounting, we accumulate value added produced by any economic agent of the economy. But, necessarily, production in national

\footnotetext{
${ }^{1}$ (B.A., M.Sc., Ph.D., Post-Doc.) Research Professor of Economics, Monetary and Banking Research Academy, bijan@bidabad.com http://www.bidabad.com.

Presented at the 3rd International Conference on Economics, Political, Law and Fiscal Sciences (EPLS '14), World Scientific and Engineering Academy and Society (WSEAS). Transilvania University of Brasov, Brasov, Romania.
} 
income accounting does not mean creating a physical product. In general term, any transaction produces positive or negative value added, and the amount of value added is calculated when the transaction occurs. Another point to remember is: in the macroeconomic frame of analysis, we have only one type of commodity under the title "value added". So, in this regard, we just deal with value added as the only macro-commodity produced by the economy. Assume that trade is in balance, and the quantity and value of imports are equal to those of exports. This assumption is due to the transactional nature of foreign trade. That is, the imports and exports of goods and services are equal to their transaction values. However, we will release this assumption later.

We examine two extreme processes of value-added production and then mix them together to reach an operational form of the real production process. By integrated production process, we mean that the process of "value added macro commodity" production is sequential and value added is produced by using previously produced value added as input. Suppose that there exist many firms and they only produce one commodity, namely, "value added". Each firm receives input (in terms of value added) from his previous firm and gives output (in terms of value added) to the next firm. In this case, the cost of production of the latest firm is equal to the accumulation of costs of all previous firms. This means that the latest produced value added includes all of the previously produced values added as input or cost. In contrast to this process, we will refer to the disintegrated production process. The latter process considers again many firms, but with this characteristic that the production of one firm necessarily is not used as input for the next firm. However, these two processes will be more explained through the text. Here, let us go through the first process of the integrated value-added production process.

\subsection{Integrated production process}

Suppose that an agent (or firm) (say agent 0 ) in the economy possesses a commodity (or service) (call it $\mathrm{C}_{0)}$ having the price of $\mathrm{P}_{0}$ in the market. This agent sales his commodity to another agent (say agent 1 ) with a new price of $\mathrm{P}_{1}$ that this new price is equal to the previous price $\left(\mathrm{P}_{0}\right)$ plus some earned profits $\left(\mathrm{Y}_{1}\right)$ by agent 0 . That is,

$$
\mathrm{P}_{1}=\mathrm{P}_{0}+\mathrm{Y}_{1}
$$

The amount of $\mathrm{Y}_{1}$ is the value added of this transaction. To perform this transaction, agent 1 should pay $\mathrm{P}_{1}$ units of money to agent 0 . Thus the amount of money payment required to create $Y_{1}$ units of value added is equal to $P_{1}$ units. If we denote $T_{1}$ as the value of the transaction in the first round, then we have the following equation;

$$
\mathrm{T}=\mathrm{T}_{1}=\mathrm{P}_{1}
$$

Where, " $\mathrm{T}$ " is the total value of transactions. In national income accounting words, we say that commodity $\mathrm{C}_{1}$ has been produced and at this moment belongs to the agent 1 .

Total value added at this round is equal to $\mathrm{Y}_{1}$. Denote "Y" as total nominal value added, at this round, we have;

$$
\mathrm{Y}=\mathrm{Y}_{1}
$$

This point should be emphasized that why " $\mathrm{Y}$ " (or " $\mathrm{Y}_{1}$ ") does not include " $\mathrm{P}_{0}$ ". According to national income accounting rules, we should not include the value of produced goods in the past periods (i.e., last years) in the current period (i.e., current year) total value added. Because this value had been calculated in the previous years and included in the previous years' income accounts.

In the second round, agent 1 uses commodity $C_{1}$ to produce $C_{2}$ commodity. He then sales it to agent 2 with the price of $\mathrm{P}_{2}$, which is equal to $\mathrm{P}_{1}$ (the price of $\mathrm{C}_{1}$ ) plus some amount of value added $\left(\mathrm{Y}_{2}\right)$ that agent 1 receives. Thus,

$$
\mathrm{P}_{2}=\mathrm{P}_{1}+\mathrm{Y}_{2}
$$

The required amount of nominal payment for this transaction is equal to $\mathrm{P}_{2}$. Thus, we denote;

$$
\mathrm{T}_{2}=\mathrm{P}_{2}
$$

Where, $\mathrm{T}_{2}$ stands for the value of transaction of the second round. The total value of transactions $(\mathrm{T})$ at this stage will be equal to the sum of transactions values of the rounds 1 and 2 . That is;

$$
\mathrm{T}=\mathrm{T}_{1}+\mathrm{T}_{2}
$$


Total value added at this stage is equal to,

$$
\mathrm{Y}=\mathrm{Y}_{1}+\mathrm{Y}_{2}
$$

In the third round, agent 2 uses $\mathrm{C}_{2}$ commodity to produce $\mathrm{C}_{3}$ commodity. Then, he sales $\mathrm{C}_{3}$ to agent 3 with the price of $\mathrm{P}_{3}$. The new price $\left(\mathrm{P}_{3}\right)$ is equal to the $\mathrm{P}_{2}$ price plus his earned profit $\mathrm{Y}_{3}$. Amount of $\mathrm{Y}_{3}$ is equal to value added produced in this round. Thus;

$$
\mathrm{P}_{3}=\mathrm{P}_{2}+\mathrm{Y}_{3}
$$

The nominal payment for this transaction $\left(\mathrm{T}_{3}\right)$ is equal to $\mathrm{P}_{3}$. That is;

$$
\mathrm{T}_{3}=\mathrm{P}_{3}
$$

The total value of transactions of rounds 1,2 , and 3 is equal to the sum of transaction values at different rounds. That is;

$$
\mathrm{T}=\mathrm{T}_{1}+\mathrm{T}_{2}+\mathrm{T}_{3}
$$

Total produced value added will be equal to;

$$
\mathrm{Y}=\mathrm{Y}_{1}+\mathrm{Y}_{2}+\mathrm{Y}_{3}
$$

Now, let us go the $\mathrm{J}^{\text {th }}$ round. Similarly, we may state that agent $\mathrm{J}-1$ uses commodity $\mathrm{C}_{\mathrm{J}-1}$ to produce commodity $\mathrm{C}_{\mathrm{J}}$. Then he sales $C_{J}$ to agent "J" with the price of $P_{J}$. That is $P_{J}$ is equal to the price of the commodity $C_{J-1}\left(\right.$ equal to $P_{J-1}$ ) plus the earned profit of agent $\mathrm{J}-1$ (equal to the amount of $\mathrm{Y}_{\mathrm{J}}$ ). Thus, we have;

$$
P_{J}=P_{J-1}+Y_{J}
$$

The nominal payment for this transaction is equal to $\mathrm{P}_{\mathrm{J}}$. Therefore;

$$
\mathrm{T}_{\mathrm{J}}=\mathrm{P}_{\mathrm{J}}
$$

The total value of transactions of all " $\mathrm{J}$ " rounds is equal to the sum of transaction values at different rounds. That is;

$$
\mathrm{T}=\mathrm{T}_{1}+\mathrm{T}_{2}+\ldots+\mathrm{T}_{\mathrm{J}}
$$

Total production value added in the economy will be equal to;

$$
\mathrm{Y}=\mathrm{Y}_{1}+\mathrm{Y}_{2}+\ldots+\mathrm{Y}_{\mathrm{J}}
$$

Now, let us derive the relation between the value of transactions ( $\mathrm{T}$ ) and total value added in the economy by solving (3) to (17). It is clear that total value added in the economy at any round "J" is simply derived by (17). This relation calculates national income in national income accounting framework. So, total income at any round " $\mathrm{J}$ " is equal to;

$$
\mathrm{Y}=\sum_{j=1}^{J} Y j
$$

Price of the commodity $\mathrm{C}_{\mathrm{J}}$ at round " $\mathrm{J}$ " is simply derived by solving difference equation (14) with initial condition (3). That is;

$$
\begin{aligned}
& \mathrm{P}_{1}=\mathrm{P}_{0}+\mathrm{Y}_{1} \\
& \mathrm{P}_{2}=\mathrm{P}_{1}+\mathrm{Y}_{2}=\mathrm{P}_{0}+\mathrm{Y}_{1}+\mathrm{Y}_{2} \\
& \mathrm{P}_{3}=\mathrm{P}_{2}+\mathrm{Y}_{3}=\mathrm{P}_{0}+\mathrm{Y}_{1}+\mathrm{Y}_{2}+\mathrm{Y}_{3} \\
& \text { : }: \quad: \quad: \quad: \quad: \quad:
\end{aligned}
$$




$$
\mathrm{P}_{\mathrm{J}}=\mathrm{P}_{\mathrm{J}-1}+\mathrm{Y}_{\mathrm{J}}=\mathrm{P}_{0}+\mathrm{Y}_{1}+\mathrm{Y}_{2}+\mathrm{Y}_{3}+\ldots+\mathrm{Y}_{\mathrm{J}}
$$

On the other hand we may write;

$$
\mathrm{P}_{\mathrm{J}}=\mathrm{P}_{0}+\sum_{\mathrm{j}=1}^{\mathrm{J}} \mathrm{Yj}_{\mathrm{j}}
$$

Total value of transactions at round "J" will be simply derived from (16), (15) and (14) as follows;

$$
\begin{aligned}
& \mathrm{T}=\mathrm{T}_{1}+\mathrm{T}_{2}+\ldots \mathrm{T}_{\mathrm{J}}=\mathrm{P}_{1}+\mathrm{P}_{2}+\ldots+\mathrm{P}_{\mathrm{J}}= \\
& \mathrm{P}_{0}+\mathrm{Y}_{1}+ \\
& \mathrm{P}_{0}+\mathrm{Y}_{1}+\mathrm{Y}_{2}+ \\
& \mathrm{P}_{0}+\mathrm{Y}_{1}+\mathrm{Y}_{2}+\mathrm{Y}_{3}+ \\
& \dot{5} \quad \dot{ } \quad \dot{ } \cdot+ \\
& \dot{\mathrm{P}_{0}}+\mathrm{Y}_{1}+\mathrm{Y}_{2}+\mathrm{Y}_{3}+\ldots+\mathrm{Y}_{\mathrm{J}}
\end{aligned}
$$

Therefore

\begin{tabular}{|c|c|c|c|c|c|c|}
\hline $\bar{J}$ & $\overline{\mathbf{C j}}$ & $\mathbf{Y j}$ & $\bar{Y}$ & $\overline{\mathbf{P j}}$ & $\overline{\mathbf{T j}}$ & $\bar{T}$ \\
\hline 0 & $\mathrm{C}_{0}$ & 0 & 0 & $\mathrm{P}_{0}$ & 0 & 0 \\
\hline 1 & $\mathrm{C}_{1}$ & $\mathrm{Y}_{1}$ & $Y_{1}$ & $\mathrm{P}_{0}+\mathrm{Y}_{1}$ & $\mathrm{P}_{0}+\mathrm{Y}_{1}$ & $\mathrm{~T}_{1}$ \\
\hline 2 & $\mathrm{C}_{2}$ & $\mathrm{Y}_{2}$ & $Y_{1}+Y_{2}$ & $\mathrm{P}_{0}+\mathrm{Y} 1+\mathrm{Y}_{2}$ & $\mathrm{P}_{0}+\mathrm{Y} 1+\mathrm{Y}_{2}$ & $\mathrm{~T}_{1}+\mathrm{T}_{2}$ \\
\hline 3 & $\mathrm{C}_{3}$ & $\mathrm{Y}_{3}$ & $Y_{1}+Y_{2}+Y_{3}$ & $\mathrm{P}_{0}+\mathrm{Y} 1+\mathrm{Y}_{2}+\mathrm{Y}_{3}$ & $\mathrm{P}_{0}+\mathrm{Y} 1+\mathrm{Y}_{2}+\mathrm{Y}_{3}$ & $\mathrm{~T}_{1}+\mathrm{T}_{2}+\mathrm{T}_{3}$ \\
\hline . & . & . & . . . . . & . . . & . . . & . . . \\
\hline . & . & . & $\cdot \cdot \cdot \cdot \cdot \cdot \cdot$ & $\begin{array}{cccccc}\cdot & \cdot & \cdot & \cdot & \cdot & \cdot\end{array}$ & $\begin{array}{cccccc} & \cdot & \cdot & \cdot & \cdot & \cdot\end{array}$ & . . . . . \\
\hline$\dot{J}$ & $\dot{\mathrm{C}}_{\mathrm{J}}$ & $\dot{\mathrm{Y}}_{\mathrm{J}}$ & $\dot{\mathrm{Y}_{1}}+\ldots \dot{+} \cdot \dot{\mathrm{Y}_{\mathrm{J}}}$ & $\dot{\mathrm{P}}_{0}+\dot{\mathrm{Y} 1}+\ldots \cdot \dot{\mathrm{Y}_{\mathrm{J}}}$ & $\mathrm{P}_{0}+\dot{\mathrm{Y}} 1+\ldots \cdot \dot{\mathrm{Y}_{\mathrm{J}}}$ & $\dot{\mathrm{T}_{1}}+\ldots \dot{ }+\dot{\mathrm{T}}_{\mathrm{J}}$ \\
\hline
\end{tabular}

$$
\mathrm{T}=\sum_{\mathrm{j}=1}^{\mathrm{J}} \mathrm{Tj}=\sum_{\mathrm{j}=1}^{\mathrm{J}} \mathrm{Pj}=\mathrm{JP}_{0}+\sum_{\mathrm{j}=1}^{\mathrm{J}} \sum_{k=1}^{j} Y_{\mathrm{k}}
$$

Different production stages and corresponding variables regarding our analysis are depicted in table 1. At this point, we should emphasize on some necessary points. First, we are talking about nominal income and nominal value of transactions and not real income and not the volume of transactions. Second, we are also talking about the price of a commodity as the market value of that commodity.

Table 1.

$\mathrm{j}:$ Production round.

$\mathrm{C}_{\mathrm{j}}$ : Produced commodity at round $\mathrm{j}$.

$\mathrm{Y}_{\mathrm{j}:}$ Produced value added at round $\mathrm{j}$.

Y: Cumulative value added.

$\mathrm{P}_{\mathrm{j}}$ : Price of commodity at round $\mathrm{j}$.

$\mathrm{T}_{\mathrm{j}}$ : Transaction value at round $\mathrm{j}$.

T: Cumulative transaction value.

When we have only one initial commodity as initial input $\left(\mathrm{C}_{0}\right)$ and process of value-added production is of integrated type (like our simple explanation), the relation of transaction value and income can be simply shown by (22). This integrated production process has a structure similar to figure 1.

Integrated production process

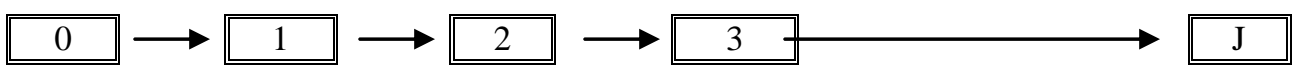

Figure 1.

Since we are focusing on macro-frame of analysis, we can use a continuous form of (18) through (22) relations. Because we have many commodities and many production processes and finally only one "commodity" under the title of income or value added is produced, we may accept that in total income formation, the amount of $\mathrm{Y}_{\mathrm{j}}$ in (18) is 
very very small during the period of production, but their number $(\mathrm{J})$ is very large relatively. However, this is actually highly realistic, since, on the average, if we divide annual income of the economy to a total number of seconds in a year we will see that the amount of economy's value-added produced in a second is very small (though a total number of seconds in a year is very large). This leads us to use a continuous form of relation (18). That is instead of discrete sum we can use integral sign. Let;

$$
d \mathrm{Y}=\underset{\mathrm{Y}_{\mathrm{j}} 0 \longrightarrow}{\lim } \mathrm{Y}_{\mathrm{j}}
$$

Where, $d$ stands for differential. Note that $\mathrm{Yj}$ is: produced value added at round " $\mathrm{j}$ ". This means that it is the difference of the total value added at round " $\mathrm{j}$ " minus total value added at round $\mathrm{j}-1$. So, in the discrete case, it is the differences between the total value-added variables of two sequential rounds. Thus, we can easily adopt it as a differential of the total value added in the continuous case as (23). In this regard, $d \mathrm{Y}$ means very small changes in total value added.

Now, we can rewrite (18) by using (23) as;

$$
\mathrm{Y}=\int_{0}^{\mathrm{J}} d \mathrm{Y}=\mathrm{J}-0=\mathrm{J} \quad====>\quad \mathrm{Y}=\mathrm{J}
$$

Now, consider the relation (20). The variable $\mathrm{P}_{\mathrm{J}}$ expresses the amount of money payment that one should pay to buy the final produced commodity $\mathrm{C}_{\mathrm{J}}$ (at round $\mathrm{J}$ ). From this payment, $\mathrm{P}_{0}$ is the amount one pays and buys the commodity, and no value added is produced by this purchase (transaction). The remaining amount of $\mathrm{P}_{\mathrm{J}}$ is that amount of payment to buy commodity $\mathrm{C}_{\mathrm{J}}$ that is equal to the total value added produced by the production of $\mathrm{C}_{\mathrm{J}}$. This decomposition of the transaction is very important in our "exchange theory of money" Bidabad (1994). However, the continuous form of (20) can be written as the sum of these two components. That is;

$$
\mathrm{P}_{\mathrm{Y}}=\mathrm{P}_{0}+\mathrm{Y}=\mathrm{P}_{\mathrm{J}}=\mathrm{P}_{0}+\mathrm{J}
$$

The third and fourth parts of (25) come from the result of (24).

In relation (22), the amount of $\mathrm{JP}_{0}$ is the amount of transaction value which does not produce value added. Let us denote this amount by $\mathrm{T}_{0}$. In this regard, in a continuous frame, we can use the following procedure to get an equation similar to (22). By (22) and (24) we have;

$$
\mathrm{T}=\int_{0}^{\mathrm{Y}} \mathrm{P}_{\mathrm{Y}} d \mathrm{P}_{\mathrm{Y}}=\int_{0}^{\mathrm{J}} \mathrm{P}_{\mathrm{Y}} d \mathrm{P}_{\mathrm{Y}}
$$

Replace (25) in (26) (and since $d \mathrm{P}_{0}=0$ ), gives;

$$
\mathrm{T}=\int_{0}^{\mathrm{Y}}\left(\mathrm{P}_{0}+\mathrm{Y}\right) d\left(\mathrm{P}_{0}+\mathrm{Y}\right)=\int_{0}^{\mathrm{Y}} \mathrm{P}_{0} d \mathrm{Y}+\int_{0}^{\mathrm{Y}} \mathrm{Y} d \mathrm{Y}
$$

Thus we will have;

$$
\mathrm{T}=\mathrm{P}_{0} \mathrm{Y}+1 / 2 \mathrm{Y}^{2}=\mathrm{P}_{0} \mathrm{~J}+1 / 2 \mathrm{~J}^{2}
$$

as the continuous form of (22). Note that in deriving (28), we can also use the following relation instead of the double sums on the right-hand side of (22);

$$
\int_{0}^{Y} \int_{0}^{X} d \mathrm{z} d X=1 / 2 \mathrm{Y}^{2}
$$

Where, "Y", "X" and "Z" replaced for "J", "j" and "K" as continuous form variables respectively. In (28), it should be noted that all variables are in values. Explicitly, 
T: Total value of transactions.

Y: Total nominal value added (income).

$\mathrm{P}_{0}$ : Total price (or value) of produced commodities in previous periods and are used as input in the current period.

In (28), the total value of transactions has been divided into two segments. One is that portion of tran sactions that do not produce value added. These transactions are equal to $\mathrm{T}_{0}$ as;

$$
\mathrm{T}_{0}=\mathrm{P}_{0} \mathrm{Y}=\mathrm{P}_{0} \mathrm{~J}
$$

The other segment is that portion of transactions that produce value added. Amount of these transactions is equal to half of the square of total value added in the economy. That is $1 / 2 \mathrm{Y}^{2}$.

\subsection{Disintegrated production process}

As we noted before in this process in contrast to the integrated process, produced value added of a firm is not used as input for the other firm. This means that intermediate demands for commodities do not exist and all productions are used for final demand; in contrast to integrated process which says final demand exists whenever we stop the production; and demands for commodities are of the intermediate type. To understand the details of this opposite extreme process, we again go through the steps that value added is produced. The schematic shape of this type of process is shown in figure 2 below.

\section{Disintegrated Production Process}

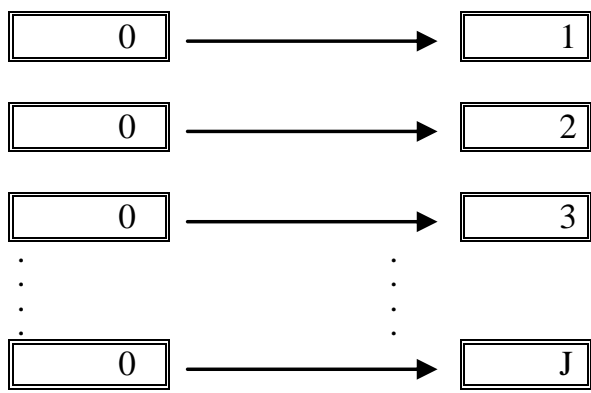

Figure 2

Suppose that agent 0 has "J" units of $\mathrm{C}_{0}$ commodity, having a unique price of $\mathrm{P}_{0}$. He sales these commodities to agents $1, \ldots, \mathrm{J}$ with new prices of $\mathrm{P}_{1}, \ldots, \mathrm{P}_{\mathrm{J}}$. So, in national income accounting, we say commodities $\mathrm{C}_{1}, \ldots, \mathrm{C}_{\mathrm{J}}$ have been produced. Agent 0 's profit from each of these transactions is equal to $\mathrm{Y}_{1}, \ldots, \mathrm{Y}_{\mathrm{J}}$. The market prices and transaction values of these commodities are equal to;

$$
\begin{aligned}
& \mathrm{T}_{1}=\mathrm{P}_{1}=\mathrm{P}_{0}+\mathrm{Y}_{1} \\
& \vdots \\
& \dot{\mathrm{T}_{\mathrm{J}}}=
\end{aligned}
$$

Where, $\mathrm{T}_{\mathrm{j}}$ is the transaction value of the $\mathrm{j}^{\text {th }}$ transaction. At this point, the production of value-added ceases. In compare to table 1 , table 2 can be considered for the disintegrated production process. Total value added to the economy will be equal to;

$$
\mathrm{Y}=\sum_{\mathrm{j}=1}^{\mathrm{J}} \mathrm{Y}_{\mathrm{j}}
$$


Table 2.

\begin{tabular}{|c|c|c|c|c|c|c|c|}
\hline $\mathbf{j}$ & $\overline{\mathbf{C j}}$ & $\overline{\mathbf{Y j}}$ & $\bar{Y}$ & $\overline{\mathbf{P j}}$ & $\mathbf{T} \mathbf{j}$ & \multicolumn{2}{|c|}{$\mathbf{T}$} \\
\hline 0 & $\mathrm{C}_{0}$ & 0 & 0 & $\overline{\mathrm{P}_{0}}$ & 0 & 0 & \\
\hline 1 & $\mathrm{C}_{1}$ & $\mathrm{Y}_{1}$ & $\mathrm{Y}_{1}$ & $\mathrm{P}_{0}+\mathrm{Y}_{1}$ & $\mathrm{P}_{0}+\mathrm{Y}_{1}$ & $\mathrm{~T}_{1}$ & \\
\hline 2 & $\mathrm{C}_{2}$ & $\mathrm{Y}_{2}$ & $Y_{1}+Y_{2}$ & $\mathrm{P}_{0}+\mathrm{Y}_{2}$ & $P_{0}+Y_{2}$ & $\mathrm{~T}_{1}+\mathrm{T}_{2}$ & \\
\hline 3 & $\mathrm{C}_{3}$ & $\mathrm{Y}_{3}$ & $Y_{1}+Y_{2}+Y_{3}$ & $\mathrm{P}_{0}+\mathrm{Y}_{3}$ & $\mathrm{P}_{0}+\mathrm{Y}_{3}$ & $\mathrm{~T}_{1}+\mathrm{T}_{2}+$ & \\
\hline$\cdot$ & . & . & . & . & . & . & . \\
\hline . & . & . & . & . & . & . & ${ }^{\circ}$ \\
\hline . & . & . & 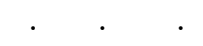 & . & & . & $. \mathrm{T}_{1}+$ \\
\hline $\mathrm{J}$ & $\mathrm{C}_{\mathrm{J}}$ & $Y_{J}$ & $Y_{1}+\ldots+Y_{J}$ & $\mathrm{P}_{0}+\mathrm{Y}_{\mathrm{J}}$ & $\mathrm{P}_{0}+\mathrm{Y}_{\mathrm{J}}$ & $\ldots+\mathrm{T}_{\mathrm{J}}$ & \\
\hline
\end{tabular}

$\mathrm{j}$ : Production round.

$\mathrm{C}_{\mathrm{j}}$ : Produced commodity at round $\mathrm{j}$.

$\mathrm{Y}_{\mathrm{j}}$ : Produced value added at round $\mathrm{j}$.

Y: Cumulative value added.

$P_{j}$ : Price of the commodity at round $j$.

$\mathrm{T}_{\mathrm{j}}$ : Transaction value at round $\mathrm{j}$.

T: Cumulative transaction value.

Total required nominal payments for all transactions will be equal to " $\mathrm{T}$ " as;

$$
\mathrm{T}=\sum_{\mathrm{j}=1}^{\mathrm{J}} \mathrm{Tj}=\sum_{\mathrm{j}=1}^{\mathrm{J}} \mathrm{Pj}=\sum_{\mathrm{j}=1}^{\mathrm{J}} \mathrm{P}_{0}+\sum_{\mathrm{j}=1}^{\mathrm{J}} \mathrm{Yj}=\mathrm{JP}_{0}+\mathrm{Y}
$$

Now let us assume again that the amount of value added produced in each round is very small. Therefore, again, the definition of (23) prevails. By this assumption we may apply (24) again to (32) and we total value of transactions for this production process as;

$$
\mathrm{T}=\mathrm{JP}_{0}+\mathrm{Y}=\mathrm{YP}_{0}+\mathrm{Y}
$$

This equation has again, similar to (30), a part of tran sactions (equal to $\mathrm{YP}_{0}$ ) that does not produce value added. The amount of $\mathrm{T}_{0}$ should be exchanged (or transacted) until we can produce "Y" units of value added.

\subsection{Mixed production process}

Operationally, the two cited before extreme cases of integrated and disintegrated production processes both occur in the economy. To combine these two processes, we use a convex combination of both. Let us use single prime (') and double prime (") symbols for integrated and disintegrated processes respectively; and symbols without prime for their convex combination. Total transactions value as a convex combination of both (28) and (34) will be equal to;

$$
\mathrm{T}=\alpha\left(\mathrm{P}_{0}^{\prime} \mathrm{Y}+1 / 2 \mathrm{Y}^{2}\right)+(1-\alpha)\left(\mathrm{P}_{0}^{\prime \prime} \mathrm{Y}+\mathrm{Y}\right)=\left[\alpha \mathrm{P}_{0}^{\prime}+(1-\alpha) \mathrm{P}_{0}^{\prime \prime}+1-\alpha\right] \mathrm{Y}+1 / 2 \alpha \mathrm{Y}^{2}
$$

Where $\alpha \epsilon[0,1]$ is a combination factor. Without loss of generality, we may use $\mathrm{P}_{0}$ as a convex combination of $\mathrm{P}_{0}{ }^{\prime}$ and $\mathrm{P}_{0}$ ". That is;

$$
\mathrm{P}_{0}=\alpha \mathrm{P}_{0}^{\prime}+(1-\alpha) \mathrm{P}_{0}^{\prime \prime}
$$

Thus, (35) can be written as;

$$
\mathrm{T}=\left(\mathrm{P}_{0}+1-\alpha\right) \mathrm{Y}+1 / 2 \alpha \mathrm{Y}^{2} \quad 0 \leq \alpha \leq 1, \mathrm{P}_{0} \geq 0
$$

When $\alpha=1$, equation (36) is the extreme case of integrated production process $\left(\mathrm{P}_{0}=\mathrm{P}_{0}{ }^{\prime}\right)$ and when $\alpha=0$, it explains the extreme case of disintegrated production process $\left(\mathrm{P}_{0}=\mathrm{P}_{0}{ }^{\prime \prime}\right)$. In $(37)$, value of those transactions that do not produce value-added is again equal to (30). 


\section{Total transaction and foreign trade}

In the previous section, we had assumed that trade is in balance, and imports are equal to exports in the economy. On the other hand, our equation (37) implies for absorption as the following equation explains, where " $\mathrm{A}_{\mathrm{n}}$ " stands for nominal absorption and " $\mathrm{B}_{\mathrm{n}}$ " for the nominal balance of trades;

$$
\mathrm{T}_{\mathrm{A}}=\left(\mathrm{P}_{0}+1-\alpha\right) \mathrm{A}_{\mathrm{n}}+1 / 2 \alpha \mathrm{A}_{\mathrm{n}}{ }^{2} \quad \mathrm{~B}_{\mathrm{n}}=0,0 \leq \alpha \leq 1, \mathrm{P}_{0} \geq 0
$$

The left-hand side variable $\mathrm{T}_{\mathrm{A}}$ denotes transactions value due to absorption. Now assume that balance of trade is not equal to zero, and let's find the amount of total transactions due to foreign trade. In the case of exports, the amount of produced value added equals to the value of exports is purchased by foreign countries from home country. There is a reverse case for imports, that is, the foreigner's produced value added is purchased by home country. Thus, the total exports are equal to the total value of transactions due to exports. A similar case occurs for imports. In transactions inside the border of a country, one is the purchaser, and one is a seller. In a transaction with a foreign country, one purchase (imports) and one sells (exports) commodity. Total value added outflow is equal to exports, and total value added inflow is equal to imports. Total transacted value with foreigners will be equal to net exports (exports minus imports). In this regard, we can write down the following equation,

$$
\mathrm{T}_{\mathrm{B}}=\mathrm{Ex}_{\mathrm{n}}-\operatorname{Im}_{\mathrm{n}}
$$

Where, $T_{B}, E_{n}$ and $\operatorname{Im}_{n}$ denote transactions value due to the foreign sector, nominal values of exports and imports respectively. Total transaction in the economy will be the sum of internal and external transactions as;

$$
\mathrm{T}=\mathrm{T}_{\mathrm{A}}+\mathrm{T}_{\mathrm{B}}
$$

Or, on the other hand, we will have;

$$
T=\left(P_{0}+1-\alpha\right) A_{n}+1 / 2 \alpha A_{n}^{2}+B_{n} \quad 0 \leq \alpha \leq 1, P_{0} \geq 0
$$

This equation shows the relation of the total transaction with absorption and balance of trade.

\section{Quantity Theory of Money, Reformulated}

Now, we are going to reformulate the quantity theory of money and constructing the link between money and income via transaction by applying our important conclusion from the previous section given by equation (41). Other economists propose that (2) is a good (but not complete) substitute for (1), but, in "The purchasing power of money", Fisher explicitly derives (1) that money required to handle all transactions multiplied by its velocity should be equal to the value of transactions. Other revisionists tried to link the total value of transactions to total nominal income in a loosed base and introduced (2). In (2), the main problem or pitfall is the assumption that they used real income as exactly the same (scale) variable as the volume of transactions. This was the mistake they undertook. A scale variable with coefficient one $(\mathrm{Y}=1 * \mathrm{t}$, or $\mathrm{Y}=1 * \mathrm{~T})$ is really a great specification error. In equation (37), we showed that the total value of transactions actually has a parabolic relation with nominal income. Therefore, we can reformulate Fisher's quantity theory of (1) by using (41) as;

$$
M V=\left(P_{0}+1-\alpha\right) A_{n}+1 / 2 A_{n}^{2}+B_{n}=T=P t \quad 0 \leq \alpha \leq 1, P_{0} \geq 0
$$

Simply, we may include the notion of the general price level and real output (or output at constant price) by using the following simple identity (given constant foreign price);

$$
\mathrm{Y}=\mathrm{Py}=\mathrm{P}(\mathrm{A}+\mathrm{B})=\mathrm{A}_{\mathrm{n}}+\mathrm{B}_{\mathrm{n}} \quad \mathrm{A}_{\mathrm{n}}=\mathrm{PA}, \mathrm{B}_{\mathrm{n}}=\mathrm{PB}
$$

Using this definitional identity in (42) we will have the following fundamental relation as a reformulation of the quantity theory of money;

$$
\mathrm{MV}=\left(\mathrm{P}_{0}+1-\alpha\right) \mathrm{PA}+1 / 2 \alpha(\mathrm{PA})^{2}+\mathrm{PB}=\mathrm{T}=\mathrm{Pt} \quad 0 \leq \alpha \leq 1, \mathrm{P}_{0} \geq 0
$$

This relation once relates money in circulation to total transactions and then relates total transactions to income components in the economy. It is interesting to note that in (44) if we use $\alpha=P_{0}=0$, we again will reach the 
equation of $\mathrm{MV}=\mathrm{Py}$ as a special case of our formulation. In this case, by $\alpha=0$, we mean the production process is disintegrated, and by $\mathrm{P}_{0}=0$, we mean no initial valued input is used in the process of value-added production.

\section{Empirical Analysis}

Let us now test our important proposition of (37) empirically for the data of the United States. Thus, we are going to test the relation between the total value of transactions and nominal income as specified by the following regression equation.

$$
T_{t}=\beta_{1} Y_{t}+\beta_{2} Y_{t}^{2}+u_{t}
$$

Where;

$\mathrm{T}_{\mathrm{t}}$ : Total value of transactions at time $\mathrm{t}$.

$\mathrm{Y}_{\mathrm{t}}$ : $\quad$ Nominal income at time $\mathrm{t}$.

$\mathrm{u}_{\mathrm{t}}$ : Disturbance term.

$\beta_{1,} ß_{2:}$ Regression coefficients.

For the sake of simplicity, in this model, we assumed that PB is a component of random error term obeying classical assumptions of least square regression. This assumption is not strong and does not affect our results so much. According to this specification, the estimated values of $\beta_{1}$ and $\beta_{2}$ should have the following restrictions.

$$
\begin{aligned}
& \beta_{1}=P_{0}+1-\alpha \geq 0 \\
& 0 \leq \beta_{2}=\alpha / 2 \leq 1 / 2
\end{aligned}
$$

Another test is to be performed is equation (45) accompanying with intercept term $\beta_{0}$. That is;

$$
T_{t}=\beta_{0}+\beta_{1} Y_{t}+\beta_{2} Y_{t}^{2}+u_{t}
$$

If our proposition is true, we should reach significant $\beta_{1}$ and $\beta_{2}$ in (45) and (48) within the interval given by (46) and (47) and insignificant $\beta_{0}$ in (48). Since transaction data is not available, similar to previous researches, we employ total debits and its modifications as proxies for a total value of transactions. The debit data captures the values of initial, intermediate, and final transactions. Therefore, according to our previous discussions, debits data will be more consistent with what we mean by the transaction.

To calculate total debits, we combined debits on demand deposits as a proxy for total deposit transactions and three different types of debits on currency as proxies of total currency transactions. To account for the level of currency transactions, we follow the assumptions and data applied by Komijani (1983). In this regard, three alternative scenarios adopted to approximate total debits, namely, $\mathrm{T}^{(1)}, \mathrm{T}^{(2)}$ and $\mathrm{T}^{(3)}$ with the following definitions;

$\mathrm{T}^{(1)}=$ Debits on demand deposits in all commercial banks.

$\mathrm{T}^{(2)}=$ Debits on demand deposits in all commercial banks $+15 \mathrm{x}$ (stock of currency).

$\mathrm{T}^{(3)}=$ Debits on demand deposits in all commercial banks + The dollar value of the amount of currency "received and counted" by Federal Reserve System.

To test the equations (45) and (48) with above three proxies for the total value of transactions, we used the data provided by Komijani (1983) for the period of 1952 - 1980 for the United States of America (there is no updated

\begin{tabular}{|c|c|c|c|c|c|c|c|}
\hline No. & $\begin{array}{l}\text { Dep. } \\
\text { Var. }\end{array}$ & $\begin{array}{c}\text { B0 } \\
\left(\mathrm{SBO}^{\wedge}\right)\end{array}$ & $\begin{array}{c}B 1 \\
\left(\mathrm{~S} \beta 1^{\wedge}\right)\end{array}$ & $\begin{array}{c}B 2 \\
\left(\mathrm{SB2} 2^{\wedge}\right)\end{array}$ & $\begin{array}{c}\text { Rho } \\
\text { (Srho) }\end{array}$ & $\mathbf{R 2}$ & $\begin{array}{c}\text { Duration } \\
\text { Watson }\end{array}$ \\
\hline 1 & $\mathrm{~T}_{\mathrm{t}}^{(\mathrm{I})}$ & - ---------- & $\begin{array}{c}2.3236 \\
(0.6327)\end{array}$ & $\begin{array}{c}0.0080 \\
(0.0003)\end{array}$ & $\begin{array}{c}0.3572 \\
(0.2228)\end{array}$ & 0.9971 & 1.3708 \\
\hline 2 & $\mathrm{~T}_{\mathrm{t}}^{(2)}$ & - & $\begin{array}{c}3.1624 \\
(0.6357) \\
\end{array}$ & $\begin{array}{c}0.0079 \\
(0.0003) \\
\end{array}$ & $\begin{array}{c}0.3514 \\
(0.2258) \\
\end{array}$ & 0.9972 & 1.3769 \\
\hline 3 & $\mathrm{~T}_{\mathrm{t}}^{(3)}$ & ------------- & $\begin{array}{c}2.3793 \\
(0.6328)\end{array}$ & $\begin{array}{c}0.0080 \\
(0.0003)\end{array}$ & $\begin{array}{c}0.3562 \\
(0.2233)\end{array}$ & 0.9971 & 1.3710 \\
\hline 4 & $\mathrm{~T}_{\mathrm{t}}^{(1)}$ & $*-80.416 *$ & 2.4620 & 0.0080 & 0.3509 & 0.9971 & 1.3747 \\
\hline
\end{tabular}
transactions value data). The Cochrane-Orcutt procedure of estimation applied to the models (45) and (48). The results of the calculations are depicted in table 3.

Table 3. 


\begin{tabular}{cccccccc}
\hline \multicolumn{1}{c}{} & & $(1069.66)$ & $(1.9902)$ & $(0.0007)$ & $(0.2505)$ & & \\
\hline 5 & $\mathrm{~T}_{\mathrm{t}}^{(2)}$ & $*+85.912 *$ & 3.0158 & 0.0080 & 0.3568 & 0.9972 & 1.3736 \\
& & $(1080.53)$ & $(2.0054)$ & $(0.0007)$ & $(0.2467)$ & & \\
\hline \multirow{2}{*}{4} & $\mathrm{~T}_{\mathrm{t}}^{(3)}$ & $*-61.996^{*}$ & 2.4855 & 0.0080 & 0.3515 & 0.9971 & 1.3739 \\
& & $(1071.71)$ & $(1.9939)$ & $(0.0007)$ & $(0.2504)$ & & \\
\hline
\end{tabular}

* Insignificant

The first three rows are corresponded to equations (45) and completely confirm our hypothesis and model specification with special attention to the conditions of (46) and (47). The rows of four through six of the table correspond to the model (48). These rows also confirm our hypothesis that the estimated intercept should be insignificant. All other calculated statistics confirm our hypothesis strongly.

\section{References}

Bidabad, Bijan [2014] General monetary equilibrium. Lap Lambert Academic Publishing, OmniScriptum GmbH \& Co. KG, ISBN: 978-3-659-54045-5, Spring 2014.

Crystal, K.A. [1990]. (ed.) Monetarism, vol. I, II; Edward Elgar.

Cuthbertson, K. [1989]. The supply and demand for money. Basil Blackwell Inc., Cambridge.

Dean, E. [1965], (ed.), The controversy over quantity theory of money, D.C. Health \& Company, a division of Raytheon education company Lexington, Massachusetts.

Fisher, D. [1980], Monetary theory and demand for money, Martin Robertson pub., Oxford.

Fisher, I. [1911], The purchasing power of money, its determination and relation to credit, interest and crises; assisted by H.G. Brown, reprinted by Augustus M. Kelly bookseller, 1963, New York.

Frenkel, J.A, H.G. Johnson [1980], (eds.), The monetary approach to balance of payment, $4^{\text {th }}$ impression, George Allen \& Unwin England.

Friedman, M., A.J. Schwartz [1982], Monetary trends in the United States and United Kingdom, their relation to income, price and interest rates 1867-1975, National Bureau of Economic Research.

Hume, D. [1752], of money, in writings on economics, edited by Eugene Rotwein (University of Wisconsin Press, 1970). Reprinted of selected essays from political discourses, 1752.

Johnson, H. G. [1979 ], (ed.), Selected Essays in Monetary Economics, $2^{\text {nd }}$ impression, George Allen \& Unwin, London.

Keynes, J.M. [1936], General theory of employment, interest, and money, Macmillan, London.

Komijani, A. [1983], Analysis of the modified money demand function and test for its stability through alternative econometric techniques; Ph.D. dissertation, University of Wisconsin - Milwaukee.

Laidler, D.E.W [1969]. The definition of money: theoretical and empirical problems, Journal of money, credit and banking, Aug.

Laidler, D.E.W. [1977], The demand for money: theories and evidence, $2^{\text {nd }}$ ed., Harper \& Row Inc., New York.

Mayer T. [1990], (ed.), Monetary theory, Edward Elgar, London.

Newlyn, W.T. [1974], Theory of money, Oxford University Press.

Patinkin, D. [1965]. Money, interest and prices, an integration of monetary and value theory, $2^{\text {nd }}$ ed., Harper \& Row, New York.

Pesek, B.P. [1979], Modern bank deposits, and the theory of optimum money, in economic perspective, an annual survey of economics. M.S. Ballabon (ed.), Baruch College of the City University of New York, Vol. I, Harwood Academic Publishers, Chur, New York.

Pierce, D.G., D.M. Shaw [1974], Monetary economics, theories, evidence, policy; London, Butterworth.

\section{Copyrights}

Copyright for this article is retained by the author(s), with first publication rights granted to the journal. This is an open-access article distributed under the terms and conditions of the Creative Commons Attribution license (http://creativecommons.org/licenses/by/4.0/) 